\title{
DIGITAL MUSICIANSHIP IN THE LATE MODERN CULTURE OF MEDIATION: THEORIZING A NEW PRAXIS FOR MUSIC EDUCATION FROM A PRAGMATIST VIEWPOINT' ${ }^{1}$
}

\begin{abstract}
In this article, author examines how digital mediation may change the way musicianship is conceived in the late modernity. Author will discuss the theoretical implications of confronting this change in music education, suggesting that recognizing its creative potential may offer a renewed theoretical perspective in music education. Author will also argue that Deweyan pragmatism can offer a fruitful way to frame the central role of mediation in music education in the late modernity.

The aim of this study is to discuss some ideas related to digital mediation and digital musicianship from the perspective of late modernity, as well as argue for a pragmatist theoretical approach for these issues.

The article is philosophical; its main materials are literature of digital culture, mediation and music education.
\end{abstract}

Keywords: digital culture, musicianship, mediation, music education, pragmatism

\section{INTRODUCTION}

Some time ago author's eyes were caught by an opinion piece in Helsingin Sanomat, the leading daily newspaper of his own country (Helsingin Sanomat Nov 5, 2011). The writing argued for the role of media education as an integrated subject in school - an argument that has been a constant in Finnish pedagogical discourse for years (see, e.g., Kupiainen \& Sintonen 2009; Kupiainen, Sintonen \& Suoranta, 2008). What made this particular communication interesting was that the writer listed several school subjects that would benefit from media education perspectives. However, there was no mention of music.

In a later issue of the same newspaper (Helsingin Sanomat Dec 17, 2011) a news story appeared that illuminated the music politics of the Finnish game company Rovio, known for its phenomenally successful Angry Birds game series. According to the story, the company takes music in its products very seriously, insisting that professional musicians produce the soundtracks of its games. The story made author realize that probably the most widespread Finnish piece of music in terms of global mediation is the Angry Birds Theme Song: after all, the piece accompanies the gaming activities of millions of people and provides raw material for hordes of remixers who distribute their creative efforts in YouTube and other media sharing sites. However, it is hard to find discussion of Angry Birds music - or, indeed, of any game music - in current music education scholarship. ${ }^{2}$

These cases are of course just scratching the surface of the complex issue of how digital media influences contemporary music culture. However, author suggests that they can direct our focus away from conventional theorizing of music education, pointing at new possibilities of interpreting the significance and value of music in human growth. Moreover, they can inform a 
new theoretical outlook that takes mediation as one of the most important aspects of contemporary music culture and recognizes the pedagogical implications of this in ways that are relevant to our theoretical understandings of the role of music pedagogy in the late modernity.

\section{THE AIM OF THIS STUDY}

To discuss some ideas related to digital mediation and digital musicianship from the perspective of late modernity, as well as argue for a pragmatist theoretical approach for these issues.

\section{MATERIALS AND METHODS \\ Late modernity}

The term "late modernity" has been frequently applied in cultural studies and sociology (see, e.g., Bauman, 2000; Beck, 1992; Giddens, 1991). The concept builds on the idea that people living in contemporary cultures and societies find themselves in a condition that is a logical consequence of, rather than an abrupt break with, the themes that framed modernity. Instead of accepting the total fragmentation of culture and society, theorists of late modernity seek the permanence from change itself, arguing that previous modernist notions do not fit as such into the new conditions, and suggesting new vocabularies for renewing these notions.

One developer of these new vocabularies, Zygmunt Bauman (2000), has argued that a defining feature of late (or "liquid") modernity is that it transforms the conditions of identity work. Whereas in the conditions of the "solid modernity", a subject could build her identity on a sound ideological basis provided by her immediate community, in late modernity she is dependent on a complex and dynamic network of social and cultural orientations that does not offer such binding forces of "mutual engagement" (Ibid. 11). Identity, in these conditions, becomes a matter of "continuous oscillations" between different subject positions rather than a static point of reference (Ibid.).

According to both A. Giddens (1991) and Z. Bauman (2000), late modernity has also brought with itself a renewed relationship of modern subject to time and space (see also Partti \& Karlsen, 2010). Whereas "solid" modernity saw time as the "means which needed to be husbanded and managed prudently so that the returns of value, which were space, could be maximized", in the new era "of software, of light modernity, the effectiveness of time as a means of value-attainment tends to approach infinity, with the paradoxical effect of levelling up (or rather down) the value of all units in the field of potential objectives" (Bauman, 2000, 118). This new relationship of time and space brings with it the need of the subject to base her life-goals on modality rather than on certainty. In these conditions, "progress is no longer a temporary measure .. leading eventually (and soon) to a state of perfection ... but a perpetual and perhaps never-ending challenge ... the very meaning of "staying alive and well"' (Bauman, 2000, 143).

Bauman finds late modernity an "epoch of disengagement, elusiveness, facile escape and hopeless chase"- an era defined by commercialism, globalism, and a ceaseless quest for meaning from superficial phenomena (Ibid. 120). For him, liquid modernity "augur[s] the advent of light, free-floating capitalism, marked by the disengagement and loosening of ties linking capital and labor" (Ibid. 149). This loosening of the ties between capital and labor is carried on by mediating technologies that tend to turn identities into performatives. As Lasch put it in his study on The Culture of Narcissism (1979, 97, quoted in Bauman, 2000, 84): "[m]odern life is so thoroughly mediated... that we cannot help responding to others as if their actions - and our own - were being recorded and simultaneously transmitted to an unseen audience or stored up for close scrutiny at some later time". 
This centrality of the role of mediation in identity formation and social bonding brings forth important ethical and pedagogical implications: late modernity introduces its own economy of the self that is largely dependent on communication through media. This economy frames fields "of potential objectives" that provide liquid identities with temporary coordinates in their ceaseless strive to become subjects in the socially and economically framed processes of individualization (Ibid.). Education has an important function in introducing people to the politics of such becoming; hence, education remains a critical project in late modernism.

\section{Mediation}

In its most broad sense, mediation can be taken simply as "coming in between." This root meaning gets different colorings in different theoretical domains. Thus, L. Grossberg et al. (2006) suggest that the term can refer to (1) "reconciliation", (2)" the difference between reality and its interpretation", (3) "the space between subject and reality", and to (4) the "connection that creates the circuit of the communication of meanings." Author shall use the term here primarily in the fourth sense, emphasizing mediation as a communicative channel that makes negotiation of shared meanings - and identities - possible. ${ }^{3}$

Even if research on mediation has become commonplace in musicology (see, e.g., Hennion, 2003; Born, 2005; Leman, 2008; Mantere, 2008), there is a lack of these studies in music education. ${ }^{4}$ There might be several reasons for this. Firstly, a major part of music education research has focused on methods of instruction in formal educational environments: thus, music pedagogy has been conceived largely as an interaction between music teacher and student in musical classroom (in schools or in dedicated music institutions). This situation, however, has changed lately along with a growing interest in informal learning. Research on informal learning has brought forth new possibilities to define music education and introduced alternative ways to conceive the pedagogical significance of mediation in music (see, e.g., Finney \& Burnard, 2007; Folkestand, 2006; Green, 2008; Karlsen, 2010; Karlsen \& Väkevä, 2012; Partti 2012; Salavuo, 2006). As G. Folkestand (2006) suggests, today's music education scholars would do disservice to their field if they only focused on what goes on in musical classrooms. It should be recognized that people learn music in various ways inside and outside formal education, and music education researchers should be interested in all the ways music makes its impact in human life - including those that build on mediation.

Another reason for the lack of interest in mediation in music education research might be that in the last years, the theoretical focus of many music educators has been on musical practice. This interest has been informed by philosophy of music education. For instance, P. Alperson (1991), J. Elliott (1995), T. Regelski (1996) and W. Bowman (1998) have argued that music educators should understand music as a praxis - as "something people do, know that they do and are known to do" in a given social-cultural context (Sparshott, cited in Elliott 1995, 42-43). While this philosophical focus on musical practice has provided new conceptual tools to the theoretical self-reflection of the profession and made possible conceiving music education, and music itself, as communicative fields (see also, Small, 1977, 1998), it has not yet really addressed the complex issue of music-related mediation. Author has argued elsewhere (Väkevä, 2009, 2010) that we could use pragmatism as a frame in which mediation and communication become central aspects of making sense of music education in theoretical terms.

\section{Deweyan pedagogical view on theory and mediation}

As in author's previous writings (Väkevä, 2006, 2007, 2009; see also, Väkevä \& Westerlund, 2007, 2011), he follows here John Dewey's pragmatist notion of the organic 
relation between theory, practice, and education. According to this notion, theory is not a general reflection of how things are: it does not represent factual relations between states of matters, nor does it reveal the logical constitution of the world. Rather, theories, and their constituent parts (ideas and concepts), are tools that help us to realize values. This realization of values - both in the sense of making them real and grasping them in their relations to other values - takes place through the process of inquiry that uses theorizing as an instrument (see, e.g., Dewey, 1910/MW $8,1938 / \mathrm{LW} \mathrm{12).}{ }^{5}$

Dewey's instrumentalist view on theory thus sees the latter as a function of practice: we theorize in order to form active relationships with our environment, and these relationships determine whether a theory is sound or not in practical terms. Because our environment is as much social as it is physical, theorizing is as much about human relationships as about control. Another way to put this is that theories inform praxis - "praxis" here indicating a practice, the practitioners of that have become conscious of what they are about and the need for deliberation of the ethical implications of this consciousness. Thus, to theorize is to mediate in the forth sense of the term as discussed above: a theory establishes a circuit of communication between people interested in achieving shared goals.

As we grasp things in their relationships, these relationships are revealed to us in shared experience through being mediated (Väkevä, 2009). Experimenting with things to realize their possible relationships and, consequently, their value potential, is conducive to growth. Growth marks the expansion of the field of agency that helps people to live meaningfully together. Theorizing is thus integral to education, and the ultimate goal of educational praxis is social growth, mediated by inquiry (Dewey, MW 9/1916).

Even if Dewey's ideas were developed decades before the current discussions of late modernity emerged, it is significant how the problems he faced were similar to the issues that concern the theorists of late modernity (cf. Diggins, 1994; Boisvert, 1998). Among these was the question of how modern subject can build an identity amidst the rapidly growing cultural networks of mediation. In Deweyan reference, this problem is intertwined with the pedagogical question of how to educate individuals for a society in constant change. Although Dewey had no way to forecast the complexity of the present information society, he did see the danger in keeping to traditional notions of formal instruction when learning increasingly takes place through informal encounters mediated by rapidly developing technology and mobility (Dewey 1916/MW 9; see also Dewey 1938/MW 13, 329-224).

It is significant that Dewey emphasized the role of "medium" as a cornerstone of learning (Dewey 1916/MW 9, 15). It is through a "medium" that we share our conjoint inquiries, and it is the task of the educator to cater for this sharing by organizing "genuine environments". It can be argued that in a culture that lives on its mediations, there is no need to limit the educational medium to the classroom. As Dewey put it, all "things with which a man [sic] varies are his genuine environment", and this also pertains to "things which are remote in space and time" (Ibid. 15). However, a teacher still can have a role in actualizing the pedagogical potential of the medium (Muhonen \& Väkevä, 2012). Perhaps most importantly, the teacher can "balance the various elements in the social environment, and to see to it that each individual gets an opportunity to escape from the limitations of the social group in which [s] he was born, and to come into living contact with a broader environment" (Dewey 1916/MW 9, 24-25). Hence, there is an ethical need for the teacher to make herself an integral part of the "genuine environment" of learning she is organizing. It is the duty of every educator (including the music educator) to help 
her/his student to find a voice amidst the complex networks of mediation. This reminds us of the political significance of teacher's effort in times when identity projects become more and more dependent on shifting cultural coordinates.

\section{DIGITAL ARTISTRY AND MEDIATION: THE CASE OF APPROPROATION}

According to C. Mullen and J. Rahn, "digital artistry" refers to how "digital and computer-based technologies [are] used to mediate [artistic] communication." (Mullen \& Rahn, $2010,1)$ The term "artistry" implies that there is more at stake than technological savvy: digital artistry involves "skills and knowledge grounded in the arts" and these skills and knowledge are put in action in artistic practice to convey aesthetic values (Ibid. 5). Another key term here is "communication": it is in and through communication that digital artistry makes its impact. Finally, there is the term "mediate": digital artistry is dependent on mediation, and it is especially at home with the "new media" that feed late modern economies.

P. Levy argues that digital artistry (he calls it "the art of cyberspace" (Levy, 1996, 336)) involves (1) utilization of communication networks, (2) liquidation of authorship, and (3) culture of appropriation. All these are important for thinking over music education theory in the digital age, and also for grasping what is at stake in the musical mediations of late modernity. Author will focus here primarily on the theme of appropriation, tracing out connections between the aesthetics of the digital expression, the idea of liquidating authorship, and the networked distribution of creative activities and their outcomes.

According to H. Emme and D. Bergland, appropriation involves "moving a digital object from one location to another" that leads into its "deconstruction, recombination, and remixing" (Emme \& Bergland, 2010, 211) the object in a new frame of reference. Appropriated objects are drawn from previous works, and it is part of the appeal of the new works that they have this material reference to their predecessors. Digital art brings meanings invested in pervious artworks into new settings of interpretation, manifesting novel ideas that, hopefully, the audience can find interesting enough to reward attention.

It is important to acknowledge that appropriation is as much a process of mediation as any epistemic practice. Creating "a circuit of the communication" between the artists and the audiences, appropriation is a self-conscious rhetoric way to join in the self-reflective praxis of art. In the digital culture, this approach is made tangible through hands-on manipulation of material signifiers derived from previously published works: the media itself becomes mediated through digital technology (Mullen \& Rahn, 2010, 2). Thus, in the context of digital art, appropriated media content can be best understood intertextually: by becoming aware of its cultural connections to past expressions, but also the new semantic overtones that may emerge in the new contexts of appropriation. "It's not just how you create, but the context of the activity that makes the product", and the context is conditioned by creative recycling of mediating tradition to an artistic effect (Jordan \& Miller, 2008, 97).

Does appropriation liquidate authorship and, in this way, miss the possibility of authenticity, hence thwarting the identity projects of the artists? The answer may be affirmative, but only if we insist that authenticity requires an authentic artwork as a sign of original expression. However, if we think of authenticity in the frame of Dewey's pragmatism, it may be also argued that, whatever authentic power the artwork has, this power is connected to how the work brings people together in an inquiry to share understandings and realize new values. In this sense, all artworks can be seen as collective efforts, nodes in the systems of mediation. As Dewey (1934/ LW 10) put it, it is what art product does to us that determines its value as an artwork. 
It is remarkable how well this pragmatist notion of art fits to digital artistry. In digital era, audience can, and often does, participate in the production process, stretching the aestheticsemiotic field in which the artwork provides its impact. In these processes, the artist and audience roles may change places, bringing forth previously unrealized possibilities of interpretation of meanings.

J. Lethem (2008) suggests that digital culture helps us to recognize that appropriation is more than a rhetoric technique; it is a necessary feature of all artistic expression. Indeed, in a more extensive historical perspective it is hard to deny that most artworks derive in one way or the other from other artworks. It is only because of the accountability pressures of the capitalist system and the omnipresence of commerce of late modern culture that we tend to forget that art can be as much based on economy of gift as in economy of commodity. The difference between the two is that a gift establishes a feeling-bind between people, whereas a commodity does not have to leave any kind of connection between the buyer and the provider. Even if there has been a tension between these two economies since the day someone first decided to sell her works, it was only the digital age and its practices of rampant cultural cannibalism that made this tension manifest (Keller, 2008). Digital art flourishes in free-form communication between the past, today and future, mediating relationships of people that constantly seek new uses for cultural objects in shared cultural commons. In respect to the prevalence of such practices today, it would be strange to restrict art pedagogy in terms of economy of commodity (see also Väkevä, 2010).

If we do not get stuck on the issue of drawing a line between the cultural commons and private property - and author has argued elsewhere that perhaps it should not be our principal concern in music education (Väkevä, 2010) - we can focus on appropriation as a rhetoric strategy and think about its implications for art education. There might be more at stake here than mere learning of techniques of cultural recycling: D. Eyman argues that appropriation "shifts the productive techne of the rhetoric process... from... invention-driven to broader... approach that privileges arrangement as a focal activity and reclaims the importance of delivery and memory as key areas." (Eyman, 2007, 30) Another way to put this could be that digital artistry shows us how techne can be turned into praxis, in the sense discussed above.

\section{Educating for digital musicianship}

How are we to understand digital musicianship and what kind of music education can best answer to the developmental needs of such musicianship? A. Hugill offers the following definition of a digital musician:

A digital musician is one who has embraced the possibilities opened up by new technologies, in particular the potential of the computer for exploring, storing, manipulating and processing sound, and the development of numerous other digital tools and devices which enable musical invention and discovery. This is a starting point for creativity of a kind that is unlike previously established musical practice in certain respects. It also requires a different attitude of mind. These musicians will be concerned not only with how to do what they do, nor what to do, but also with why to make music. A digital musician, therefore, has a certain curiosity, a questioning and critical engagement that goes with the territory (Hugill, 2008, 4).

Hugill (Ibid. xiii) describes the digital musician as someone who has adjusted to the "seismic shift in music and particularly music education" initiated by digital culture and new media. Technology is often taken as a code for digital music production: however, Hugill argues that digital musicianship also involves "a personal aesthetic, an awareness of the context for the work, specific musical and technical abilities and an individual identity" (Ibid. xiv). Thus, digital 
musicianship should be taken as a mode of digital artistry, and as such it rewards out notions as art educators.

Like all digital artistry, digital musicianship is marked by versatility. A digital musician "originates and performs, ... creates and produces, and ... harnesses the potential of technology in new and exciting ways" in service of artistic expression (Ibid. xiv, italics original). In other words, it is the way in which a digital musician approaches music that makes her art distinctive (or not): a digital musician is willing to try any aspects of musical activity as they suit her expressive needs. ${ }^{6}$ As mentioned above, nothing prevents audience members from appropriating these kinds of methods and techniques as long as they share the access to digital archives and tools-and as long as they have a chance to develop their versatility in the frame of digital artistry. Music educators surely have an important task in making these kinds of art practices accessible: to pretend that digital artistry would be only something reserved for the talented would be to avert one's eyes of the democratizing aspects of the digital technology.

Could developing versatility even be a central goal for music education? If it would, what kinds of abilities would we cater for in terms of digital mediation? Hugill (Ibid. 4) suggests that digital musicianship is characterized by following features:

1. Aural awareness, or "an ability to hear and listen both widely and accurately, linked to an understanding of how sound behaves in space and time"

2. Musical ability, or "the capacity to make music in various ways ... using the new technologies"

3. Technical skills, or skills "in recording, producing, processing, manipulating and disseminating music and sound using digital technologies"

4. Cultural knowledge, or "an understanding of one's place within a local and global culture coupled with an ability to make critical judgments and a knowledge of recent cultural developments."

It is highly significant that this list includes cultural knowledge: it does not suffice that one learns to use technology to make, disseminate, and enjoy music: one must also possess what Lucy Green calls "critical musicality" (Green, 2008, 14, 83, 91), the ability to draw connections between musical and cultural phenomena. In K. Jordan and P. D. Miller's (Jordan \& Miller, 2008) terms, to produce art, one has to be able to read the "infinite archive" of cultural history, scattered in bits and pieces in the digital domain. If music education is to meet the demands for this kind of critical understanding, it cannot help but to conceive itself also in terms of media education. In addition to awareness, abilities, and skills, we should educate for understanding of how musical and music related messages are mediated in digital culture of late modernity, and what for,

Interestingly, Hugill also argues that a "digital musician... is not only one who uses only [digital] technologies but is rather a product of the digital culture" (Hugill, 2008, xv, italics added). In this sense, a digital artist is as much a subject as an agent of mediation. Digital culture brings forth possibilities for musicians to revision their notions of themselves and to frame their identities as musicians, thus contributing to the late modern individualization project in musical terms. Previous modes of musicianship are by no means irrelevant to this artistry: a digital musicians reflect a specific "attitude of mind" - a digital "mindset" - in which traditional musical practices and aesthetic sensibilities are assimilated (Hugill, 2008, xv, 4). Even if digital musicians may use non-digital devices and techniques, these devices and techniques are put in new uses in new contexts informed by digital culture. Hence, digital music culture may also transform our conceptions of what it takes to become a musician in a traditional sense. 
An important part of digital musicianship is the skill to apply mediation in creative purposes, both in the sense of being able to use the new media creatively and in the sense of finding new resources for existing media contents. Moreover, the ability to communicate and share musical ideas becomes central in defining musicianship as digital artistry. Today's digital native musicians dwell in the communication networks rather merely than draw information from them. This makes digital musicianship relatively independent of time and place, which has further pedagogical implications. To be a music educator in the digital era is to acknowledge, and take heed of, these implications: it is to confront the late modern culture of mediation in all of its significance to musical lives.

\section{REFERENCES}

Alperson, P. (1991). What should one expect from a philosophy of music education? Journal of Aesthetic Education, 25 (3), 215-242.

Bauman, Z. (2000). Liquid modernity. Cambridge: Polity Press.

Beck, U. (1992). Risk Society: towards a new modernity. London: Sage.

Boisvert, R. (1998). John Dewey: Rethinking our time. Albany: State of New York University Press.

Born, G. (2005). On musical mediation: Ontology, technology, and creativity. Twentieth-Century Music, 2 (1), $7-36$.

Bowman, W. (1998). The limits and grounds of musical praxialism. In D. Elliott, (Ed.), Praxial Music Education: Reflections and Dialogues (pp. 52-78).New York: Oxford University Press.

Dewey, J. The Middle Works. In The Collected Works of John Dewey, 1882-1953. Electronic edition. Charlottesville: Intelex Past Masters.

Dewey, J. The Later Works. In The Collected Works of John Dewey, 1882-1953. Electronic edition. Charlottesville: Intelex Past Masters.

Diggins, J. (1994). The Promise of Pragmatism. Chicago: University of Chicago Press.

Elliott, J. (1995). Music Matters: a New Philosophy of Music Education. New York: Oxford University Press.

Emme, M., \& Bergland, D. (2010). Unfinished: Internet aesthetics, interactive digital environments and your art classroom. In C. Mullen \& J. Rahn (Eds.), Viewfinding: Perspectives on new media curriculum in the arts (pp. 205-224). New York: Peter Lang.

Eyman, D. (2007). Digital rhetoric: Ecologies and economies of digital circulation. (Unpublished doctoral dissertation, East Lansing: Michigan State University, 2007).

Finney, J., \& Burnard, P. (2007). Music education with digital technology. London: Continuum.

Folkestand, G. (2006). Formal and informal learning situations or practices vs formal and informal ways of learning. British Journal of Music Educatio, 23 (2), 135-145.

Giddens, A. (1991). Modernity and self-identity: self and society in the late modern age. Cambridge: Polity Press.

Green, L. (2008). Music, informal learning and the school: a new classroom pedagogy. Aldershot: Ashgate.

Grossberg, L., Wartella, E. D., Whitney, C., \& Macgregor Wise, J. (Eds.). (2006). Mediamaking: Mass media in popular culture. Thousand Oaks: SAGE.

Hennion, A. (2003). Music and mediation: towards a new sociology of music. In M. Clayton, T. Herbert, \& R. Middleton (Eds.), The Cultural Study of Music (pp. 80-91). New York: Routledge. 
Mediakasvatus ei vaadi oppiaineen asemaa [Media education does not demand its own school subject]. Helsingin Sanomat (2011, November 5).

Angry Birdsin tekijät panostavat musiikkiin [The developers of Angry Birds invest in music]. Helsingin Sanomat (2011, December 17).

Hugill, A. (2008). The digital musician. New York, NY: Routledge.

Jordan, K., \& Miller, P. D. (2008). Freeze frame: Audio, aesthetics, sampling, and contemporary multimedia. In P. D. Miller (Ed.), Sound unbound: Sampling digital music and culture (pp. 97-108). Cambridge, MA: MIT Press.

Karlsen, S. (2010). BoomTown Music Education and the need for authenticity - informal learning put into practice in Swedish post-compulsory music education. British Journal of Music Education, 27 (1), $35-46$.

Karlsen, S., \& Väkevä, L. (2012). Future prospects for music education: Corroborating informal learning pedagogy. Newcastle upon Tyne: Cambridge Scholars Press.

Keller, D. (2008). The musician as thief: Digital culture and copyright law. In P. D. Miller (Ed.), Sound unbound: Sampling digital music and culture (pp. 135-150). Cambridge, MA: MIT Press.

Kupiainen, R., \& Sintonen, S. (2009). Medialukutaidot, osallisuus, mediakasvatus [Media literacy, participation, media education]. Helsinki: Gaudeamus.

Kupiainen, R., Sintonen, S., \& Suoranta, R. (2008). Suomalaisen mediakasvatuksen vuosikymmenet [The decades of Finnish media education]. In R. Kupiainen, H. Kynäslahti, \& M. Lehtonen (Eds.), Näkökulmia mediakasvatukseen [Viewpoints on media education]. Helsinki: Mediakasvatusseura.

Leman, M. (2008). Embodied music cognition and mediation technology. Cambridge: MIT Press.

Lethem, J. (2008). The ecstasy of influence: A plagiarism mosaic. In P. D. Miller (Ed.), Sound unbound: Sampling digital music and culture (pp. 25-52). Cambridge, MA: MIT Press.

Levy, P. (1996). The art of cyberspace. In T. Druckrey (Ed.), Electronic culture: Technology and visual representation. (pp. 366-368). New York: Aperture.

Mantere, M. (2008). Musiikin medituminen [Mediation of music]. In E. Huovinen \& J. Kuitunen (Eds.), Johdatus musiikkifilosofiaan [An introduction in philosophy of music] (pp. 131-176). Tampere: Vastapaino.

Mullen, C., \&, Rahn, J. (2010). Introduction. In C. Mullen, \& J. Rahn (Eds.), Viewfinding: Perspectives on new media curriculum in the arts. (pp. 1-30). New York: Peter Lang.

Muhonen, S., \& Väkevä, L. (2012). Seizing the dynamic moment in situation-originated learning: The origin of songcrafting examined through Dewey's theory of inquiry. Nordic Research in Music Education Yearbook 2011.

Partti, H. (2012). Cosmopolitan musicianship under construction: Digital musicians illuminating emerging values in music education. Journal of Music Education, 12/2012, 1-16.

Partti, H., \& Karslen, S. (2010). Reconceptualising musical learning: new media, identity and community in music education. Music Education Reserarch, 12 (4), 369-382.

Regelski, T. (1996). A Prolegomenon to a praxial philosophy of music education. Finnish Journal of Music Education, 1 (1), 23-40.

Salavuo, M. (2006). Open and informal online communities as forums of collaborative musical activities and learning. British Journal of Music Education, 23 (3), 253-271.

Small, C. (1977). Music, society, education: an examination of the function of music in Western, Eastern and African cultures with its impact on society and its use in education. New York: Schirmer Books.

Small, C. (1998). Musicking: the meanings of performing and listening. Hanover: University Press of New England, Wesleyan University Press. 
Väkevä, L. (2006). Teaching popular music in Finland: What's up, what's ahead? International Journal of Music Education, 24 (2), 126-131.

Väkevä, L. (2007). Art education, the art of education and the art of life. Considering the implications of Dewey's later philosophy to art and music education. Action, Criticism, \& Theory for Music Education, 6 (1). Retrieved from http://act.maydaygroup.org/articles/Vakeva6_1.pdf

Väkevä, L. (2009). The world well lost, found: Reality and authenticity in Green's "New Classroom Pedagogy." Action, Criticism \& Theory for Music Education, 8 (2). Retrieved from http://act.maydaygroup.org/ articles/Vakeva__2.pdf

Väkevä, L. (2010). Garage band or Garage Band®? Remixing musical futures. British Journal of Music Education, 27 (1), 59-70.

Väkevä. L. (2012). Digital Artistry and Mediation: (Re)mixing Music Education. National Society for the Study of Education, 111 (1), 177-195.

Väkevä, L., \& Westerlund, H. (2007). The 'Method' of Democracy in Music Education. Action, Criticism \& Theory for Music Education, 7 (4). Retrieved from http://act.maydaygroup.org/articles/Vakeva Westerlund6_4.pdf.

Väkevä, L., \& Westerlund, H. (2011). Who needs theory anyway? Theory and practice in music education in a philosophical outlook. British Journal of Music Education, 28 (1), 37-49.

\section{ENDNOTES}

1 This article is based on a keynote lecture delivered in Theory for Practice in the Education of Contemporary Society Conference, hosted and organized by Riga Teacher Training and Educational Management Academy in 29-31 March, 2012. These themes are also developed in Väkevä (2012).

${ }^{2}$ Of one exception, see Wise, Greenwood \& Davis (2011). See also the working papers of the UMSIC mobile music education project (www.umsic.org).

3 Johan Fornäs $(1995,217)$ uses in a similar context the term "mediatization" to mark "the (increasing) use of media in identity constructions". Author will here follow Roger Silverstone $(2007,109)$ who understands "mediation" as "fundamentally uneven, dialectical process in which institutionalized media are involved in the general circulation of symbols in social life"- thus contributing to the fourth sense of mediation as discussed here. See also Sintonen (2012).

${ }^{4}$ For some exceptions regarding the role of media, mediation, and media education in music education, see Burnard (2011); Hultberg (2011); Sintonen (2012); Väkevä (2009, 2010).

5 Author refers to Dewey's collected works in customary way, with original publishing year, followed by the series and volume number. Here "MW" indicates The Middle Works, "LW" The Later Works.

${ }^{6}$ An image that instantly springs into mind is that of Bjork constantly seeking new media of expression, stretching the aesthetic limits of popular music.

Prof. Dr. phil. Lauri Väkevä

Sibelius Academy, Finland

E-mail: lvakeva@siba.fi 